\title{
The use of thermophilic bacteria in accelerated hydrocarbon bioremediation
}

\author{
A. Perfumo, I. M. Banat \& R. Marchant \\ Microbial Biotechnology Group, School of Biomedical Sciences, \\ University of Ulster, Northern Ireland, UK
}

\begin{abstract}
Successful bioremediation of hydrocarbon contamination in terrestrial as well as aquatic ecosystems is generally limited by the low bioavailability of hydrophobic pollutants. Considerably higher mass transfer rates and hydrocarbon solubilities can be obtained at higher temperatures, but so far approaches to bioremediation at increased temperature have hardly been investigated. The biotechnological significance and the benefits of the use of thermophilic bacteria in enhancing hydrocarbon removal under different environmental conditions were investigated. Expression of the alkane mono-oxygenase alkB gene responsible for the initial step in the degradation of alkanes in soil geobacilli was found to be induced by the presence of such a substrate at high temperature, and this explains the increased degradation rates achieved in hexadecane-contaminated microcosms incubated at $60^{\circ} \mathrm{C}$ compared to mesophilic conditions. Additional benefits of increasing hydrocarbon degradation also occur when thermophilic bacteria capable of producing biosurfactants which act as solubilising agents in such systems are introduced. We conclude that thermally accelerated bioremediation may be an effective technology for hydrocarbon contaminated soil bioremediation.
\end{abstract}

Keywords: thermophiles, geobacilli, bioremediation, biosurfactants.

\section{Introduction}

Removal of contamination from soils, sediments, groundwater, surface water and air with hazardous and toxic compounds is a priority task for the restoration of the natural environment due to the serious threat contaminants pose to ecosystems and human health. Among the many techniques employed to 
remediate polluted sites, environmentally friendly technologies of bioremediation are gaining increasing prominence due to their obvious advantages although some disadvantages may also occur. Bioremediation is mainly carried out through the use of microorganisms or microbial processes to degrade environmental contaminants or attempts to accelerate naturally occurring biodegradation through the optimization of conditions which are otherwise limiting. A variety of bioremediation methods have been developed to support and increase the degradative activities of native microbial populations (natural attenuation), thus allowing a reduction in the time required and subsequent saving in costs. The two main approaches to bioremediation include environmental biostimulation, involving the addition of mainly oxygen and/or mineral nutrients (nitrogen, phosphorous \& trace metals), and bioaugmentation with addition of selected degrader microorganisms to the site.

Hydrocarbon-degrading microorganisms have been widely investigated both in laboratory and field studies, but so far little attention has been paid to the role and the biotechnological significance of thermophilic bacteria in bioremediation. In this paper we will briefly present the benefits of running hydrocarbon degradation processes at elevated temperature. In particular we will discuss how to detect and best exploit the degradative capability of thermophilic geobacilli inhabiting most soil environments for high temperature bioremediation treatments. We will also investigate the aspect of production of biosurfactants as an additional property of some thermophilic degrader microorganisms for further enhancing hydrocarbon removal. Some of these aspects have been introduced in recent publications [17-19,26].

\section{High temperature conditions}

Biodegradation rates are influenced by several factors both physico-chemical such as environmental characteristics, nutrients, oxygen, $\mathrm{pH}$ value, concentration and bioavailability of the contaminants, chemical characteristics and history of the pollution, and biological aspects such as number and species of indigenous microflora, abundance of degrading microorganisms. Among these factors temperature plays a significant role in controlling bioavailability of lowsolubility compounds and hence the nature and the extent of microbial metabolism and degradation [20]. The rate at which microbial cells can convert contaminants during bioremediation depends on the rate of contaminant uptake and metabolism and the rate of transfer to cells (mass transfer) [9]. The elevation of temperature is accompanied by a decrease in viscosity and an increase in the diffusion coefficient of organic compounds so that the bioavailability of recalcitrant substrates may be significantly improved allowing more efficient bioremediation [25].

\section{Thermophilic degrading microorganisms}

High numbers of thermophilic degraders have been isolated and characterized in the last few years, and their potential for hydrocarbon pollution remediation 
investigated. A representative sample of such microorganisms with possible applications in bioremediation is shown in Table 1.

The main target of thermally enhanced bioremediation processes can be waste materials such as industrial effluents, which are often discharged at $50-130^{\circ} \mathrm{C}$, and excavated contaminated soil, which could be treated in slurry reactors. The increasing number of patents indicates that there is a growing interest in the commercial application of such environmentally friendly technologies. Behmann and Tonelli [8] developed an aerated hot membrane bioreactor process for purifying any wastewater stream, and especially those containing recalcitrant compounds, suitable for treatment with thermophilic bacteria thriving in a temperature range of $45-75^{\circ} \mathrm{C}$. Lugowsky et al. [16] patented a method for detoxifying liquid effluent streams contaminated with toxic hydrocarbons using a mixture of selected thermophilic degrading bacteria, mostly belonging to Pseudomonas genus, to be inoculated in reactors operating at $40-42^{\circ} \mathrm{C}$.

Table 1: Thermophilic microorganisms potentially useful for hydrocarbon bioremediation applications.

\begin{tabular}{|c|c|c|c|}
\hline Microorganisms & Temp & Hydrocarbons & Reference \\
\hline B. thermoleovorans & $70^{\circ}$ & Long-chain alkanes & Kato et al. [15] \\
\hline $\begin{array}{l}\text { G. } \\
\text { T80 }\end{array}$ & $60^{\circ}$ & Long-chain alkanes & Marchant et al. [19] \\
\hline $\begin{array}{l}\text { B. thermoleovorans } \\
\text { DSM } 10561\end{array}$ & $45-60^{\circ}$ & Aromatic & Markl et al. [21] \\
\hline Anaerobic Consortia & $45-75^{\circ}$ & Aromatic & Chen \& Taylor [12] \\
\hline Thermus \& Bacillus sp. & $60-70^{\circ}$ & PAHs & Feitkenhauer et al. [14] \\
\hline $\begin{array}{l}\text { Consortium mainly of } \\
\text { Pseudomonas sp. }\end{array}$ & $40-42^{\circ}$ & $\begin{array}{l}\text { Aromatic } \\
\text { hydrocarbons }\end{array}$ & Lugowsky et al. [16] \\
\hline $\begin{array}{l}\text { B. thermoleovorans } \\
\text { Hamburg } 2\end{array}$ & $60^{\circ}$ & Naphthalene & Annweiler et al. [2] \\
\hline Bacillus sp. JF8 & $60^{\circ}$ & Naphthalene \& PCBs & Shimura et al. [32] \\
\hline Consortia of anaerobes & $65^{\circ}$ & $\begin{array}{l}\text { Dibenzothiophene } \\
\text { (DBT) }\end{array}$ & Bahrami et al. [3] \\
\hline B.stearothermophilus & $60^{\circ}$ & Crude oil & Sorkhoh et al. [34] \\
\hline Bacillus sp. & $40-45^{\circ}$ & Crude oil & Al-Maghrabi et al. [1] \\
\hline P.aeruginosa AP02-1 & $45^{\circ}$ & Crude \& diesel oil & Perfumo et al. [26] \\
\hline
\end{tabular}

An innovative technology exploiting thermophilic degraders has recently been described by Chaalal et al. [11]. They used thermophilic bacteria growing at $80^{\circ} \mathrm{C}$ to inoculate a suitably designed bioreactor in which solar radiation was supplied. Solar energy allowed the increase in temperature of the reactor water to a level that promoted the growth of thermophiles while ensuring airflow through transverse perforate pipes thus creating effective mixing. Coupling these factors allowed optimum conditions (e.g. decreased viscosity and interfacial tension of 
hydrocarbon contaminants, profuse emulsification and faster reaction rates) to be established and hence significantly enhanced bioremediation achieved.

Hydrocarbon-degrading thermophiles are of special significance also for accelerating bioremediation in situ, which is mostly related to contaminated hotenvironments such as arid regions. Numerous studies on oil spill bioremediation in Kuwait after the Gulf war in 1991 reported on the different strategies for the clean up of pollution. Experimental evidence indicated a potential self-cleaning of oil-contaminated areas via the activities of indigenous hydrocarbon-degrading microorganisms [33], which could be further improved by different management practices such as irrigation and fertilization with nitrogen or organic carbons [27].

Recently, a new attractive technology that couples the degradative activities of indigenous thermophiles to primary remediation methods such as Dynamic Underground Stripping (DUS) is growing in interest as well as in applications. DUS technologies combined steam injection or electrical resistance to heat subsurface areas, vaporize volatile compounds bound to soil so as to drive contaminants to vacuum extraction wells. Although steam injection can potentially recover a large fraction of volatile contaminants, it is expected that residual amounts of the contaminants will remain, and that can be further remediated by natural attenuation or bioremediation. Taylor et al. [35] patented a process in which selected microorganisms were inoculated into the injection wells thus allowing the removal of low levels of aromatic and chlorinated hydrocarbons. Due to the heating, the subsurface environment remains at elevated temperature $\left(50-70^{\circ} \mathrm{C}\right)$ for extended periods, which enables thermophilic bacteria to thrive and metabolize the residual contaminants. The Lawrence Livermore National Laboratory, USA, reported an unexpected benefit in encouraging the biological degradation of hydrocarbons during underground steam stripping of contaminated soils at temperatures above $100^{\circ} \mathrm{C}$ [24]. Such active microbial communities in underground environments maintained at temperatures between $45-75^{\circ} \mathrm{C}$ following heat treatments have been reported elsewhere [31]. Thus, there is a clear evidence of the usefulness of thermophilic bacteria in bioremediation.

\section{Use of geobacilli in thermally enhanced bioremediation of hydrocarbons}

Interest in thermophilic bacilli has been recently rekindled by the reclassification of a number of Bacillus species into new genus Geobacillus [23] coupled with the description of additional species [7]. Although many of the Geobacillus isolates have come from high-temperature environments, it has been pointed out that they are frequent in temperate-climate soil environments where they are apparently unable to grow due to the temperature restriction $[17,18]$. It has also been established that an extensive diversity of geobacilli inhabiting the soils has the capability to degrade alkanes and hydrocarbons [30]. Our current studies have been addressed to some aspects of this problem. 


\section{Induction of alkB gene in n-alkane degrading thermophilic geobacilli}

We used molecular techniques to investigate the expression of the alkane monooxygenase gene $(a l k B)$ in thermophilic geobacilli belonging to our collection [17]. Using sequence data derived from the European Molecular Biology Laboratory (EMBL) database, we designed degenerate primers for the alkB gene and succeeded in amplifying a fragment of this gene in $G$. thermoleovorans T70. An RT-PCR experiment confirmed that the $a l k B$ gene expression was induced in the presence of $n$-hexadecane in pure cultures of $G$. thermoleovorans T70 when grown at $55^{\circ} \mathrm{C}$. The same analysis was performed by extracting RNA directly from soil microcosms containing $n$-hexadecane and incubated for 1 week at 25 , 30,37 and $55^{\circ} \mathrm{C}$ together with a control microcosm with no alkane incubated at $55^{\circ} \mathrm{C}$. The results indicated that also in soil samples $a l k B$ gene was expressed only in presence of $n$-hexadecane when incubated at $55^{\circ} \mathrm{C}$. No positive RT-PCR signals were detected from any of the other microcosms. Thus, our data showed that the $a l k B$ gene in thermophilic geobacilli was induced by alkanes at high temperature.

\section{Soil microcosms}

Experiments were carried out to develop new strategies of thermally enhanced bioremediation technology for hydrocarbon-contaminated soils. Soil microcosms simulating the main bioremediation techniques (e.g. natural attenuation, biostimulation with inorganic nutrients, biosolubilisation with biosurfactants and bioaugmentation with a selected degrader strain together with an abiotic microcosm as control) to demonstrate the ability of thermophilic geobacilli to effectively degrade $2 \%(\mathrm{v} / \mathrm{v}) n$-hexadecane were set up at both $60^{\circ} \mathrm{C}$ and at ambient temperature. Hydrocarbon removal as well as the microbiological response was monitored for a 40-day period (Table 2(a) and (b)).

\section{Natural attenuation}

Elevated temperature $\left(60^{\circ} \mathrm{C}\right)$ significantly enhanced the $n$-hexadecane degradation rates in soil microcosms compared to those at ambient temperature leading to two-fold increased removal. Higher temperatures may enhance desorption of contaminants from the soil particles, mobilizing them and increasing the solubility and bioavailability. The response at $60^{\circ} \mathrm{C}$ of the autochthonous microbial population, which had a 10 -fold-increase in number, as well as the degradation rate, which was $56.4 \%$ after 40 days, demonstrated the intrinsic capabilities of the indigenous thermophiles and encouraged the development of further bioremediation treatments. 
Table 2: Soil microcosms experimental design \& hexadecane degradation under various bioremediation techniques \& number of Colony forming unites (CFU)/gram soil at (a) $60^{\circ} \mathrm{C}$ and (b) ambient temperature.

\begin{tabular}{|c|c|c|c|c|c|}
\hline \multirow{2}{*}{ No. } & \multirow{2}{*}{ Techniques } & \multirow{2}{*}{$\begin{array}{l}\text { Microcosm set- } \\
\text { up }\end{array}$} & \multirow{2}{*}{$\begin{array}{c}n \text {-Hexadecane } \\
\% \text { removal } \\
\text { at } 40 \text { days }\end{array}$} & \multicolumn{2}{|c|}{ Microbiological response } \\
\hline & & & & $\begin{array}{c}\text { Initial } \\
\text { CFU }\end{array}$ & $\begin{array}{l}\text { CFU at } \\
\text { 40days }\end{array}$ \\
\hline \multicolumn{6}{|l|}{ (a) } \\
\hline 1 & $\begin{array}{l}\text { Natural } \\
\text { attenuation }\end{array}$ & No amendments & 56.4 & $1.2 \times 10^{4}$ & $8.5 \times 10^{4}$ \\
\hline 2 & $\begin{array}{l}\text { Biostimula- } \\
\text { tion }\end{array}$ & $\begin{array}{l}\text { NPK solution at } \\
0.5 \%(\mathrm{v} / \mathrm{w})\end{array}$ & 65.3 & $2.0 \times 10^{4}$ & $2.1 \times 10^{4}$ \\
\hline 3 & $\begin{array}{l}\text { Biosolubili- } \\
\text { sation }\end{array}$ & $\begin{array}{l}\text { JBR-215 } \\
\text { rhamnolipid } \\
0.5 \%(\mathrm{v} / \mathrm{w})\end{array}$ & 71.4 & $1.6 \times 10^{4}$ & $4.5 \times 10^{4}$ \\
\hline 4 & $\begin{array}{l}\text { Bioaugme- } \\
\text { ntation }\end{array}$ & $\begin{array}{l}\text { G.thermoleovo- } \\
\text { rans } \mathrm{T} 80\end{array}$ & 70.3 & $6.5 \times 10^{4}$ & $5.0 \times 10^{4}$ \\
\hline 5 & All $2+3+4$ & All amendments & 91.0 & $6.0 \times 10^{4}$ & $7.2 \times 10^{4}$ \\
\hline 6 & $\begin{array}{l}\text { Abiotic } \\
\text { control }\end{array}$ & $\begin{array}{l}\text { Sterilized soil, } \\
\text { no amendments }\end{array}$ & 7.4 & 0 & 0 \\
\hline
\end{tabular}

(b)

\begin{tabular}{cllccc}
1 & $\begin{array}{l}\text { Natural } \\
\text { attenuation }\end{array}$ & No amendments & 29.7 & $9.5 \times 10^{5}$ & $1.3 \times 10^{6}$ \\
\hline 2 & $\begin{array}{l}\text { Biostimula- } \\
\text { tion }\end{array}$ & $\begin{array}{l}\text { NPK solution at } \\
0.5 \% \text { (v/w) }\end{array}$ & 41.3 & $7.5 \times 10^{5}$ & $1.5 \times 10^{6}$ \\
\hline 3 & $\begin{array}{l}\text { Biosolubili- } \\
\text { sation }\end{array}$ & $\begin{array}{l}\text { JBR-215 } \\
\text { rhamnolipid } \\
0.5 \% \text { (v/w }\end{array}$ & 42.5 & $5.6 \times 10^{5}$ & $2.0 \times 10^{6}$ \\
\hline 4 & $\begin{array}{l}\text { Bioaugme- } \\
\text { ntation }\end{array}$ & $\begin{array}{l}\text { G.thermoleovo- } \\
\text { rans T80 }\end{array}$ & 38.0 & $8.2 \times 10^{5}$ & $1.8 \times 10^{6}$ \\
\hline 5 & All 2 +3 +4 & All amendments & 48.5 & $8.0 \times 10^{5}$ & $4.0 \times 10^{6}$ \\
\hline 6 & $\begin{array}{l}\text { Abiotic } \\
\text { control }\end{array}$ & $\begin{array}{l}\text { Sterilized soil, } \\
\text { no amendments }\end{array}$ & 3.2 & 0 & 0 \\
\hline
\end{tabular}

\section{Biostimulation with inorganic NPK}

We applied the biostimulation with inorganic nutrients (nitrogen, phosphorous, potassium), which is one of the most widely used techniques given the rapid depletion of the pool of these essential elements as a consequence of the high carbon content due to the contamination. Our results confirmed the benefit showing an increase of approximately $10 \%$ of $n$-hexadecane degradation rates both at $60^{\circ} \mathrm{C}(65.3 \%$ reduction $)$ and at ambient temperature (41.3\% reduction). 


\section{Solubilisation with biosurfactant}

Soil microcosms treated with biosurfactants (JBR 215 rhamnolipid solution, Jeneil Biosurfactant, WI, USA) had a significant enhancement of alkane degradation, which was $71.4 \%$ and $42.5 \%$ at $60^{\circ} \mathrm{C}$ and $18^{\circ} \mathrm{C}$ respectively. These results were consistent with numerous studies demonstrating the efficacy of such molecules in remediating oil-contaminated soils [22,28,29]. It is likely that rhamnolipids, being biodegradable and containing both sugar and lipid moieties, acted as an additional carbon source thus contributing to the biodegradation enhancement.

\section{Bioaugmentation}

Bioaugmentation has frequently been reported unsuccessful since microorganisms able to degrade organic pollutants in laboratory conditions may fail to compete with indigenous microorganisms for many reasons. Bioaugmentation with indigenous microorganisms isolated from the contaminated soil, may help to overcome these problems and contribute to enhanced degradation rates. When we added Geobacillus thermoleovorans T80, an indigenous thermophilic degrading strain [18] we detected a significant increase in the $n$-hexadecane removal at high temperature $(70.3 \%)$.

\section{Combined treatment}

When all amendments were used together up to $91 \%$ of the hydrocarbon in the soil microcosms incubated at $60^{\circ} \mathrm{C}$ were removed whereas $48.5 \%$ was removed in those at $18^{\circ} \mathrm{C}$. Tables 2 (a) and (b) show details of the experimental set-up of soil microcosms as well as the effects of treatments on soil hydrocarbon degradation and soil microbial populations. These data were subjected to a three way Analysis of Variance (ANOVA), which confirmed that the combination of the bioremediation treatments with the high temperature had a highly significant effect on hydrocarbon removal.

\section{Biosurfactant-enhanced bioremediation of hydrocarbons}

Bioavailability of poorly water-soluble hydrocarbons and pollutants is low. Solvents and synthetic surfactants are frequently used as additives to improve the solubility, but they are themselves a further source of contamination and mostly hazardous to the environment. Alternatively biosurfactants are microbial products that are biodegradable and non toxic and hence more suitable for environmental applications. This explains the increasing interest on these molecules, which have been extensively studied $[4-6,13]$. 


\section{Thermophilic biosurfactant-producing microorganisms}

Oil-degradation and biosurfactant-production investigations almost exclusively deal with mesophilic microorganisms, while a few reports refer to thermophilic conditions as reviewed by Cameotra and Makkar [10]. Thermophilic biosurfactants therefore remain an unexplored microbial resource.

A biosurfactant-producing Pseudomonas aeruginosa AP02-1 was isolated from a hot spring environment and grows optimally at $45^{\circ} \mathrm{C}$ using a variety of hydrocarbons (short and long-chain alkanes, aromatic and polycyclic aromatic hydrocarbons, heterocyclic sulphorate hydrocarbons) as carbon source [26]. The strain is able to degrade crude oil and diesel oil with high efficiency: gas chromatographic analyses for cultures grown on both compounds showed $99 \%$ degradation of the total petroleum hydrocarbons (TPHs) after only 7 days of incubation [26].

The involvement and role of rhamnolipids in promoting the uptake of hydrocarbons is well known but under such thermophilic conditions the solubilisation process was accelerated. The fast dispersion of the diesel layer into oil droplets and the subsequent formation of a stable emulsion observed during the bacterial growth was attributed to biosurfactant production which led to the lowering of the surface tension coupled to an increase in the emulsification activity. The Bacterial Adhesion To Hydrocarbons (BATH) test showed $71 \%$ of cells adhered directly to hydrocarbon droplets. Clear evidence came from Scanning Electron Microscopy, which showed diesel oil droplets breaking down to smaller sizes, and after $96 \mathrm{~h}$ of incubation, bacterial cells tightly adhered to the surface of microdroplets of approximately $30-\mu \mathrm{m}$ diameter. Thus, we concluded that such a multiphase, thermally enhanced and biosurfactant-mediated process allowed $P$. aeruginosa AP02-1 to degrade almost completely diesel as well as crude oil in less than 1 week of incubation.

\section{Conclusions}

High temperature $\left(60^{\circ} \mathrm{C}\right)$ significantly enhanced $n$-hexadecane degradation in soil leading to approximately two-fold increased overall removal. The supplementation with limiting nutrients, augmentation with thermophilic geobacilli or addition of biosurfactants all contributed to additional degradation and combining all resulted in up to $90 \%$ removal of $n$-hexadecane in microcosms within 40 days. Such high degradation rates of hydrocarbons were also observed when a thermophilic biosurfactant-producing oil degrading P. aeruginosa AP021 was used and which efficiently utilised crude oil and diesel within a short period $\left(<7\right.$ days) at $45^{\circ} \mathrm{C}$. It is concluded therefore that the combination of thermal treatment for pollution removal and bioremediation has potential to be used as an effective environmental biotechnology. 


\section{Acknowledgement}

This work was funded by Environment and Heritage Service, N. Ireland, under Building Sustainable Prosperity (BSP7473) programme.

\section{References}

[1] Al-Maghrabi, I.M.A., Bin Aqil, A.O., Islam, M.R., Chaalal, O. 1999. Use of thermophilic bacteria for bioremediation of petroleum contaminants. Energy Sources. 21, 17-29.

[2] Annweiler, E., Richnow, H.H., Antranikian, G., Hebenbrock, S., Garms, C., Franke, S., Francke, W., Michaelis, W. 2000. Naphthalene degradation and incorporation of naphthalene-derived carbon into biomass by thermophilic Bacillus thermoleovorans. Appl Env Microbiol. 66, 518-523.

[3] Bahrami, A., Shojaosadati, S.A., Mohebali, G. 2001. Biodegradation of dibenzothiophene by thermophilic bacteria. Biotechnol Letters. 23, 899901 .

[4] Banat, I.M. 1995a. Biosurfactants production and possible uses in microbial enhanced oil recovery and oil pollution remediation, a review. Bioresource Technol. 51, 1-12.

[5] Banat, I.M. 1995b. Characterization of biosurfactants and their use in pollution removal-state of the art (review). Acta Biotechnol. 15, 251-267.

[6] Banat, I.M., Makkar, R.S., Cameotra, S.S. 2000. Potential commercial applications of microbial surfactants. Appl Microbiol Biotechnol. 53, 495508.

[7] Banat, I.M., Marchant, R., Rahman, T.J. 2004. Geobacillus debilis sp. nov., a novel obligately thermophilic bacterium isolated from a cool soil environment, and reassignment of Bacillus pallidus to Geobacillus pallidus comb. nov. Int J Syst Evol Microbiol. 54, 2197-2201.

[8] Behmann, H., Tonelli, F.A. 1996. Aerated hot membrane bioreactor process for treating recalcitrant compounds. Patent US5558774, September 24.

[9] Boopathy, R. 2000. Factors limiting bioremediation technologies. Bioresource Technol. 74, 63-67.

[10] Cameotra, S.S. and Makkar, R.S. 1998. Synthesis of biosurfactants in extreme conditions. Appl Microbiol Biotechnol. 50, 520-529.

[11] Chaalal, O., Tango, M., Islam, M. R. 2005. A new technique of solar bioremediation. Energy Sources 27, 361-370.

[12] Chen, C.I., and Taylor, R.T. 1997. Thermophilic biodegradation of BTEX by two consortia of anaerobic bacteria. Appl Microbiol Biotechnol. 48, 121-128.

[13] Desai, J.D. and Banat, I.M. 1997. Microbial production of surfactants and their commercial potential. Microbiol Mol Biol Rev. 61, 47-64.

[14] Feitkenhauer, H., Muller, R., Markl, H. 2003. Degradation of polycyclic aromatic hydrocarbons and long chain alkanes at $60-70^{\circ} \mathrm{C}$ by Thermus and Bacillus spp. Biodegradation 14, 367-372. 
[15] Kato, T., Haruki, M., Morikawa, M., Kanaya, S. 2001. Isolation and characterization of long-chain-alkane degrading Bacillus thermoleovorans from deep subterranean petroleum reservoirs. J Biosci Bioeng.. 91, 64-70.

[16] Lugowsky, A.J., Palamteer, G.A., Boose, T.R., Merriman, J.E. 1997. Biodegradation process for detoxifying liquid streams. Patent US5656169.

[17] Marchant, R., Banat, I.M., Rahman, T.J., Berzano, M. 2002a. The frequency and characteristics of highly thermophilic bacteria in cool soil environments. Env Microbiol. 4, 595-602.

[18] Marchant,R., Banat,I, Rahman,T., Berzano,M.2002b. What are hightemperature. bacteria doing in cold environments? Trends Microbiol. 10, 120-121.

[19] Marchant, R., Sharkey, F.H., Banat, I.M., Rahman, T.J., Perfumo, A. 2006. The degradation of $n$-hexadecane in soil by thermophilic geobacilli. FEMS Microbiol Ecol. In press.

[20] Margesin, R., Schinner, F. 2001.Biodegradation and bioremediation of hydrocarbons in extreme environments. Appl Microbiol Biotechnol.56,650-663.

[21] Markl, H., Antranikian, G., Becker, P., Markossian, S. 1999. Aerobic biodegradation of aromatic compounds having low water solubility using Bacillus thermoleovorans strain DSM 10561. Patent US5965431, October 12.

[22] Mulligan, C.N. 2005. Environmental applications for biosurfactants. Environ Poll. 133, 183-198.

[23] Nazina, T.N., Tourova, T.P., Poltaraus, A.B. et al. 2001. Taxonomic study of aerobic thermophilic bacilli: description of Geobacillus subterraneus gen. nov., sp. nov. and Geobacillus uzenensis sp. nov. from petroleum reservoirs and transfer of Bacillus stearothermophilus, Bacillus thermocatenulatus, Bacillus thermoleovorans, B. kaustophilus, B. thermoglucosidasius and B. thermodenitrificans to Geobacillus as the new combinations $G$. stearothermophilus, $G$. thermocatenulatus, $G$. thermoleovorans, G. kaustophilus, $G$. thermoglucosidasius and $G$. thermodenitrificans. Int J Syst Evol Microbiol. 51, 433-446.

[24] Newmark, R.L., Aines, R.D. 1998. They all like it hot: Faster Cleanup of contaminated soils and groundwater. Science and Technology Review; http://www.llnl.gov/str/pdfs/05 98.1.pdf. (viewed on 1 Dec. 05).

[25] Niehaus, F., Bertoldo, C., Kähler, M., Antranikian, G. 1999. Extremophiles as a source of novel enzymes for industrial application. Appl Microbiol Biotechnol. 51, 711-729.

[26] Perfumo, A., Banat, I.M., Canganella, F., Marchant, R. 2006. Rhamnolipid production by a novel thermophilic hydrocarbon-degrading Pseudomonas aeruginosa AP02-1. Appl Microbiol Biotechnol. In press.

[27] Radwan, S.S., Al-Mailem, D., El-Nemr, I., Salamah, S. 2000. Enhanced remediation of hydrocarbon contaminated desert soil fertilized with organic carbons. Int Biodeterior Biodegrad. 46, 129-132.

[28] Rahman, K.S.M., Banat, I.M., Thahira, J., Thayumanavan, T., Lakshmanaperumalsamy, P. 2002. Bioremediation of gasoline 
contaminated soil by a bacterial consortium amended with poultry litter, coir pith and rhamnolipid biosurfactant. Bioresource Technol. 81, 25-32.

[29] Rahman, K.S.M., Rahman, T.J., Kourkoutas, Y., Petsas, I., Marchant, R., Banat, I.M. 2003 Enhanced bioremediation of $n$-alkanes in petroleum sludge using bacterial consortium amended with rhamnolipid and micronutrients. Bioresource Technol. 90, 159-168.

[30] Rahman, T.J., Marchant, R., Banat, I.M. 2004. Distribution and molecular investigation of highly thermophilic bacteria associated with cool soil environments. Biochem Soc Trans. 32, 209-213.

[31] Richardson, R., James, C., Bhupathiraju, V., Alvarez-Cohen, L. 2002. Microbial activity in soils following steam treatment. Biodegradation 13, 285-295.

[32] Shimura, M., Mukerjee-Dhar, G., Kimbara, K., Nagato, H., Kiyohara, H., Hatta, T. 1999. Isolation and characterization of a thermophilic Bacillus sp. JF8 capable of degrading polychlorinated biphenyls and naphthalene. FEMS Microbiol Letters. 178, 87-93.

[33] Sorkhoh, N.A., Al-Hasan, R., Radwan, S., Höpner, T. 1992. Self-cleaning of the Gulf. Nature 359, 109.

[34] Sorkhoh, N.A., Ibrahim, A. S., Ghannoum, M.A., Radwan, S.S. 1993. High-temperature hydrocarbon degradation by Bacillus stearothermophilus from oil-polluted Kuwait desert. Appl Microbiol Biotechnol. 39, 123-126.

[35] Taylor, T.R., Jackson, K.J., Duba, A.G., Chen, C.I. 1998. In situ thermally enhanced biodegradation of petroleum fuel hydrocarbons and halogenated solvents. Patent US5753122, May 19. 